\title{
Strategi Pengembangan Potensi Wisata Bahari di Pantai Atuh Desa Pejukutan Kecamatan Nusa Penida Kabupaten Klungkung
}

I Putu Ngurah Wibawa a,1 I Nyoman Sunarta a,2

11ngurahwibawa1@gmail.com²nyoman_sunarta@unud.ac.id

a Program Studi Sarjana Destinasi Pariwisata, Fakultas Pariwisata, Universitas Udayana, Jl. Dr. R. Goris, Denpasar, Bali 80232 Indonesia

\section{Abstract}

Pejukutan Village has very good natural and maritime potential, one of which is Atuh Beach's tourism potential which has a white sand beach with very good reefs, Melonteng Hill, Tree House, Diamond Clip besides that at Atuh Beach, there are 4 (four) islands large coral, namely Batu Melawang or Pepadasan Island, Batu Paon Island, Batu Abah Island and Batu Jineng Island, this is one of the attractions of Atuh Beach.

In this study, the data obtained by way, observation, in-depth interviews, documentation studies, literature study. Using data types in the form of qualitative and quantitative, while the data source in the form of primary data and secondary data. Data analysis used in this research is descriptive qualitative analysis and analysis SWOT matrix (Strength, Weaknesses, Opportunities, Threats).

The results research is Atuh Beach as a marine tourism and natural tourism with the potential possessed such as the scenery possessed by Atuh Beach which is flanked by two hills from the left and right, underwater scenery, has coral islands such as Batu Melawang Island or Pepadasan (Batu Bolong), Batu Paon Island, Batu Abah Island and Batu Jineng Island, Melonteng Hill, Throwing Tree House and Diamond Clip. the people of Pcantutan Village are mostly farmers. Aside from being a farmer in the Potanutan Village community, they are also craftsmen in weaving and raising livestock. The Village of Pejukutan has Baris Jangkang Dance, this dance is performed when accompanying certain ceremonies.

\section{Keyword : Strategy Development, Potency, Maritime Tourism}

\section{PENDAHULUAN}

Industri pariwisata merupakan salah satu industri yang ada di Indonesia sebagai bentuk yang potensial untuk dikembangkan baik itu alam dan budaya karena Indonesia yang memiliki kaya akan potensial kepariwisataan. Pariwisata di Indonesia dianggap mampu menuntaskan kemiskinan di Indonesia. Sektor pariwisata tidak hanya dapat meningkatkan devisa untuk pembangunan yang dilakukan pemerintah, tetapi mampu dapat menuntaskan kemiskinan. Dewasa ini sektor pariwisata merupakan sektor yang penting dan memiliki pengaruh yang cukup nyata dalam perkembangan ekonomi Negara. Kontribusi pariwisata dianggap penting bagi pertumbuhan ekonomi di Indonesia, karena selain mendatangkan devisa, juga dirasakan mampu membuka lapangan kerja baru bagi masyarakat. Pemerintah Indonesia juga terlihat peka menghadapi perkembangan pariwisata di Negara ini.

Melalui upaya yang dilakukan secara terencana demi tercapainya tujuan yang dinginkan, pengembangan pada hakekatnya memiliki makna yang sama dengan pembangunan yaitu proses perubahan ke arah yang lebih baik. Pembangunan sebagai proses perubahan dapat diartikan pula sebagai proses perbaikan material maupun sosio-kultural dan usaha memajukan kehidupan spiritual suatu masyarakat. Aspek ekonomi, sosial, budaya, dan politik, yang berlangsung baik pada level makro (nasional) maupun mikro (daerah) dari proses pembangunan atau pengembangan yang dapat terjadi di semua aspek didalamnya.

Salah satu pengembangan yang berpengaruh dalam beberapa aspek seperti sosial, politik, ekonomi dan budaya adalah pengembangan pariwisata. Pariwisata senantiasa berkembang secara dinamis seiring dengan kondisi lingkungan strategis, baik lokal maupun global. Berwisata bagi sebagian masyarakat bertujuan untuk menciptakan ketenangan fisik maupun psikis agar dapat beraktivitas dengan baik pula, atau hiburan mendapatkan kepuasan lahir dan batin.

Desa Pejukutan merupakan Desa yang ada di Pulau Nusa Penida Bali memiliki potensi yaitu alam dan bahari yang menarik, salah satunya potensi wisata Pantai Atuh yang memiliki pantai pasir putih dengan karangkarang yang sangat bagus, Bukit Melonteng, Rumah Pohon, Diamond Clip selain itu di Pantai Atuh terdapa 4 (empat) pulau karang yang besar yaitu Pulau Batu Melawang atau Pepadasan, Pulau Batu Abah dan Pulau Batu Jineng Pulau Batu Paon ini merupakan 
dayatarik wisata di Pantai Atuh. Pulau Batu Melawang merupakan bagian pulau yang terbesar yang ada di DTW Pantai Atuh, pulau ini memiliki sebuah lubang yang besar seperti bentuk terowongan besar. Pasir putih yang dimiliki Pantai Atuh, air laut yang biru ketika surut dapat melihat karang-karang yang bagus selain itu pada pagi hari wisatawan dapat melihat sunrise di pantai atuh.

Kawasan Pantai Atuh yang memiliki beberapa potensi wisata khususnya potensi wisata bahari memiliki peluang dan berpotensi dikembangkan lebih optimal lagi dan tata kelola yang lebih baik maka dari itu diperlukan menggali potensi wisata Pantai Atuh dan strategi pengembangan wisata di Pantai Atuh.

\section{KEPUSTAKAAN}

\subsection{Tinjauan Penelitian Sebelumnya}

Penelitian ini mengambil tinjauan penelitian sebelumnya dengan membandingkan beberapa jurnal. Adapun Penelitian yang pertama oleh I Gede Anom Sastrawan dan I Nyoman Sunarta (2014). Penelitian ini membahas mengenai Strategi Pengembangan Potensi Wisata Bahari di Pantai Crystal Bay Nusa Penida dengan memiliki focus penelitian yang sama. Penelitian kedua yaitu penelitian yang dilakukan oleh Fitri Damayanti, Razak, Benu Olfie L. Zusana dan Gene H. M. Kapantow (2017) mengenai Strategi Pengembangan Wisata Bahari Pantai Malalayang, Kota Manado, Sulawesi Utara dengan memiliki focus yang sama yakni strategi pengembangan wisata bahari.

\subsection{Tinjauan Konsep}

Penelitian ini menggunakan lima konsep untuk menganalisis dan mebedah permasalahan dalam tulisan jurnal ini yaitu konsep pariwisata (Nurhayati,2002), konsep daya tarik (Sunarta,2011), konsep potensi wisata (pendit,1994), Konsep wisata bahari (nsep wisata bahari (keraf,2002), konsep strategi pengembangan (Yoeti,2008).

\section{METODE PENELITIAN}

Penelitian ini mengambil lokasi di Nusa Penida tepatnya di DTW Pantai Atuh, Desa Pejukutan Kecamatan Nusa Penida Kabupaten Klungung. Data primer dari penelitian ini adalah hasil wawancara dan observasi menegnai potensi pantai atuh yang di dapat secara langsung di lokasi penelitian, Data skunder dalam penelitian ini yaitu hasil tinjauan penelitian jurnal dan literatureliteratur yang memiliki masalah yang sama.

Teknik pengumpulan data menggunakan Teknik observasi dengan mengamati secara langsung untuk mendapatkan gambaran tentang strategi pengembangan potensi wisata bahari di Pantai Atuh. Wawancara mendalam digunakan untuk bertanya langsung kepada Kepala Desa, Pengelola daya tarik wisata, pengusaha di Pantai Atuh dan masyarakat lokal. Dokumentasi untuk mendukung keaslian data berupa video, foto dan rekaman. Selain observasi teknik yang dilakukan yakni studi Kepustakaan yang digunakan mengambil jurnal dan penelitian yang berkaitan dengan lokus dan fokus.

Dalam penelitian ini metode analisis matrix SWOT (Strenghts, Weaknesses, Opportunitties, Threats). analisis ini menggunakan menguraikan hasil dan informasi yang didapat di lokasi penelitian untuk mengetahui kondisi atau keadaan Pantai Atuh mengenai faktor eksternal yakni peluang dan ancaman yang didapat dengan menyesuaikan kekuatan dan kelemahan internal yang dimiliki Pantai Atuh..

\begin{tabular}{|c|c|c|}
\hline Eksternal & $\begin{array}{c}\text { Internal } \\
\text { Kekuatan (S) } \\
\text { Faktor } \\
\text { Kekuatan } \\
\text { Internal }\end{array}$ & $\begin{array}{c}\text { Internal } \\
\text { Kelemahan } \\
\text { (W) } \\
\text { Faktor } \\
\text { Kelemahan } \\
\text { Internal }\end{array}$ \\
\hline $\begin{array}{c}\text { Eksternal } \\
\text { Peluang (0) }\end{array}$ & $\begin{array}{l}\text { Strategi (SO) } \\
\text { Daftar untuk } \\
\text { meraih } \\
\text { keuntungan dari } \\
\text { peluang yang } \\
\text { ada }\end{array}$ & $\begin{array}{c}\text { Strategi (W0) } \\
\text { Daftar untuk } \\
\text { memperkecil } \\
\text { kelemahan } \\
\text { dengan } \\
\text { memanfaatkan } \\
\text { keuntungan dari } \\
\text { peluang yang ada }\end{array}$ \\
\hline $\begin{array}{c}\text { Eksternal } \\
\text { Ancaman } \\
\text { (T) }\end{array}$ & $\begin{array}{c}\text { Strategi (ST) } \\
\text { Daftar kekeuatan } \\
\text { untuk } \\
\text { menghindari } \\
\text { ancaman }\end{array}$ & $\begin{array}{l}\text { Strategi (WT) } \\
\text { Daftar untuk } \\
\text { memperkecil } \\
\text { kelemahan dan } \\
\text { menghindari } \\
\text { ancaman }\end{array}$ \\
\hline
\end{tabular}

Matrik SWOT

Analisis SWOT, Rangkuti 2006 


\section{HASIL DAN PEMBAHASAN \\ 4.1 Potensi Pantai Atuh}

Pantai Atuh memiliki potensi yang masih alami, seperti pasir putih, air laut yang biru, Bukit Melonteng, Rumah Pohon dan memiliki pulau-pulau karang yang sangat indah terdapat empat yakni Pulau Batu Paon, Pulau Batu Abah dan Pulau Batu Jineng pulau karang Pulau Batu Melawang atau Pepadasan, selain itu juga Pantai Atuh juga memiliki daya tarik wisata bahari seperti berenang, memancing, snorkling dan berjemur.

\subsubsection{Potensi Fisik}

1. Pulau Karang Pantai Atuh

Pantai Atuh yang memiliki pulau pulau karang, terdapa 4 (empat) pulau karang yang paling besar yaitu Pulau Batu Melawang atau Pepadsan, Pulau Batu Abah dan Pulau Batu Jineng, Pulau Batu Paon Pulau yang paling besar yaitu pulau melawang, masyarakat sekitar sering menyebutnya dengan (Batu Bolong) karena terdapat terowongan di dalamnya. Di sekitaran Pulau Batu Abah merupakan tempat hidupnya ikan mola-mola salah satu spot diving yang ada di Pantai Atuh. Pemandangan wisata alam yang ada di Pantai Atuh berpotensi dan memiliki peluang dikembangkan menjadi daya tarik wisata bahari.

\section{Diamond Clip}

Diamond Clip yang berlokasi di sebelah Pantai Atuh yang diapit oleh dua, pulau karang yang berbentuk kerucut seperti Diamond ini memiliki ketinggian lebih kurang 8 meter dan meyajikan panorama pantai yang masih alami, Diamond Clip Atuh ini merupakan daya tarik wisata yang baru. Untuk menuju ke Diamond Clip dengan melewati ratusan anak tangga di sisi tebing.

3. Bukit Melonteng Nusa Penida

Pantai Atuh memiliki daya tarik wisata tersendiri di antara Pantai-Pantai yang ada di Kabupaten Klungkung. Keunikan yang di miliki bukit ini bisa melihat pulau-pulau karang yang ada di Pantai Atuh, pulau-pulau yang ada di Pantai Atuh sering disebut 1000 (seribu) pulau atau Raja 5 (lima) oleh masyarakat sekitar maupun wisatan lokal, karena memiliki pulau-pulau kecil yang cukup banyak, namun hanya ada empat pulau yang ada nama yaitu pulau karang yang paling besar Pulau Batu Melawang, Pulau Batu Abah, Pulau Batupaon, dan Pulau Batu Jineng pulau tersebut yang dapat di lihat dari atas Bukit Melonteng. dan juga terdapat daya tarik wisata Rumah Pohon Melonteng, yang ada di Bikit Melonteng tersebut.

\subsubsection{Potensi Non Fisik}

1. Kegiatan Sehari-hari

Kegiatan sehari-hari yang di lakukan masyarakat Desa Pejukutan yang sebagian besar sebagai petani. Selain sebagai petani masyarakat Desa Pejukutan juga sebagai pengerajin tenun dan beternak. Kegiatan sehari-hari ini bisa menjadi daya tarik wisata jika di jual atau di jadikan paket wisata, selain itu wisatawan juga dapat pengalam baru seperti belajar cara menenun dengan ini pendapatan masyarakatpun dapat bertambah.

\section{Seni Tari}

Tari Baris Jangkang Merupakan tarian sakral yang ada di Desa Pejukutan, tari ini di pentaskan untuk mengiringi proses upacara tertentu, selain di Pentaskan di Pura Tari Baris Jangkang Juga di pentaskan di rumah ketika melaksanakan Upacara Dewa Yadnya (Upacara Daur Hidup) dan Upacara Sesangi (Membayar Kaul). Secara rutin tari ini di pentaskan di upacara di Pura Desa. Pementasan Tari Baris Jangkang pada saat penonton tidak boleh rebut dan berkata kasar, jika melanggar maka penonton tersebut akan mendapatkan petaka seperti sakit, kecelakaan dan yang lainnya.

\subsection{Strategi Pengembangan Pantai Atuh}

\section{Strategi (Strenght -Opportunities)}

Strategi

Strenght-Opportunities

(kekuatan-peluang) memanfaatkan peluang dengan melihat potensi yang menjadi kekuatan Pantai Atuh untuk dapat memanfaatkan peluang yang ada di Pantai Atuh. Mempromosikan Pantai Atuh sebaga daya tarik wisata melalui media sosial dan mendia cetak seperti baliho. Mengajak pemilik homestay, pemilik warung, travel agent untuk 
berpartisipasi untuk ikut mempromosikan Pantai Atuh, semakin banyak yang ikut mempromosikan kemungkinan besar untuk di ketahui banyak orang dan mendatangkan pengunjung melalui travel agent. Memperbaiki sara dan prasarana untuk mendukung kegiatan pariwisata dan menambah pendapatan desa melalui kegiatan dan kunjungan wisatawan di Pantai Atuh Desa Sakti.

\section{Strategi (Strenght - Threats)}

Strategi Strenght-Threats (kekuatanancaman) ini untuk menghadapi ancaman dengan memanfaatkan kekuatan yang di miliki Pantai Atuh. Menonjolkan kelebihan yang di miliki Pantai Atuh, yang memiliki pasir putih, birunya air laut, pemandangan bawah laut, pulau karang, Diamond Clip, Bukit Melonteng, rumah pohoh, dan keidanahan pantai yang di apit dua tebing sisi kri dan kanan. Memberikan pembekalan terkait pelestarian budaya agar masyarakat lokal dapat menjaga kebudayaan itu sendiri. Pembuatan awig-awig (peraturan) pembangunan di Pantai Atuh, Desa Pejukutan. Dengan adanya awig-awig ini dapat mengurangi pembangunan yang berlebihan dan tidak merusak lingkungan.

\section{Strategi (Weakness - Opportunities)}

Strategi Weakness - Opportunities (kelemahan - peluang), yang meminimalkan kelemahan untuk memanfaatkan peluang yang di miliki Pantai Atuh. Membuat daya tarik wisata baru dan mempromosikannya menggunakan media sosial dan cetak sehingga membuat wisatawan yang datang untuk mencoba sesuatu yang baru. Selain itu menambah dan memperbaiki toilet umum, ruang ganti, menambah tempat sampah yang ada di Pantai Atuh agar wisatawan merasa nyaman dan mudah untuk membuang sampah agar sampah tidak berserakan dan lingkungan tetap berih dari sampah.

\section{Strategi (Weakness - Threats)}

Strategi Weakness-Threats (kelemahanancaman) yang meminimalkan kelemahan dan menghindari ancaman yang di miliki Pantai Atuh. Membuat pos keamanan dan penjaga pantai agar wisatawan merasa nyaman saat menikmati kegiatan wisata di Pantai Atuh dan menghindari kejadian-kejadian yang tidak diinginkan. Memberikan wawasan tentang pariwisata dan memberikan pembinaan menjadi pemandu wisata. Memberikan wawasan dan pembinaan agar masyarakat tidak kalah bersaing dengan tenaga kerja luar daerah dan tenaga asing.

\section{PENUTUPAN \\ 5.1 Kesimpulan}

Dari hasil yang didapat makan didapat beberapa simpulan yang dapat di sampaikan. Berikut simpulan dari hasil penelitian yang dapat di jabarkan sebagai berikut :

1. Potensi fisik dan Non fisk yang di miliki Pantai Atuh sebagai berikut :

a. Potensi fisik Pantai Atuh.

Pantai Atuh yang memiliki potensi potensi wisata alam seperti pemandangan yang di miliki Pantai Atuh yang di apit dua bukit dari sisi kiri dan kanan, pemandangan bawah laut, memiliki pulau-pulau karang seperti Pulau Batu Melawang (Batu Bolong), Pulau Batu Abah dan Pulau Batu Jineng ,Pulau Batu Paon, Bukit Melonteng, Rumah Pohon Melonteng dan Diamond Clip. Di sepanjang jalan menuju Pantai Atuh akan di suguhi dengan pemandangan perkebunan masyarakat lokal dan pemandangan tebing-tebing yang cukup curam. Selain itu juga kegiatan masyarakat lokal menambah nilai potensi objek wisata seperti pengerajin tenun.

b. Potensi Non fisik Pantai Atuh.

Potensi non fisik, yang dimiliki Pantai Atuh, masyarakat Desa Pejukutan yang sebagian besar sebagai petani. Selain sebagai petani masyarakat Desa Pejukutan juga sebagai pengerajin tenun dan beternak. Adapun Desa Pejukutan memiliki Tari Baris Jangkang yang tidak di miliki Desa lain, tarian ini dipentaskan saat mengiringi proses upacara tertentu, selain di Pentaskan di Pura Tari Baris Jangkang Juga di pentaskan di rumah ketika melaksanakan Upacara Dewa Yadnya (Upacara Daur Hidup) dan Upacara Sesangi (Membayar Kaul).

c. Strategi SWOT Pantai Atuh 
Hasil penelitian yang dilakukan di Pantai Atuh menggunakan strategi SWOT (Strenght, Weaknesses, Opportunities dan Threats). dapat ditetukan potensi yang akan dikembangkan dari potensi yang dimiliki Pantai Atuh dengan mengelola daya tarik wisata yang dimiliki Pantai Atuh dengan tepat dengan menjaga kelestariannya. Mengembangkan suatu daya tarik wisata pastinya mengurangi kendala-kendala yang ada, maka dari itu untuk mengembangkan daya tarik wisata Pantai Atuh dengan mengurangi kendala yang dimiliki Pantai Atuh.

\subsection{Saran}

Beberapa saran yang dapat peneliti sampaiakan berdasarkan hasil penelitian yang di lakukaan, terdapat yaitu, sebagai berikut :

1. Memberikan wawasan tentang pariwisata dan memberikan pembinaan menjadi pemandu wisata. Memberikan wawasan dan pembinaan agar masyarakat tidak kalah bersaing dengan tenaga kerja luar daerah dan tenaga asing.

2. Membuat pos keamanan dan penjaga pantai agar wisatawan merasa tenang saat melakukan aktivitas wisata di Pantai Atuh dan menghindari kejadian-kejadian yang tidak diinginkan wisatawan.

3. Melakukan Pengaspalan jalan yang masih berlubang agar tidak menghambat perjalanan wisatawan yang menuju daya tarik wisata Pantai Atuh.

4. Menambah fasilitas tempat sampah dimasing masing dayatarik agar wisatawan tidak membuang sampah sembarangan yang berakibat merusak lingkungan yang ada di Pantai Atuh.

\section{DAFTAR PUSTAKA}

Anom Sastrawan, I Gede dan Sunarta. 2014. Strategi Pengembangan Potensi Wisata Bahari di Pantai Crystal Bay Desa Sakti Kec. Nusa Penida Kab. Klungkung.Jurnal Destinasi Pariwisata, Vol. 2 No 2

Keraf. 2000. Dimensi Budaya, Ekologi Pesisir dan Laut dalam Pengembangan Wisata Bahari. Seminar Lengkap. Denpasar: Kajian Budaya Universitas Udayana

Pendit, S. Nyoman. 1994. Ilmu Pariwisata Sebuah Pengantar Perdana, Jakarta: Pradnya Paramita

Putra, Putu Karyana dan I Nyoman Sunarta. 2018. Identifikasi Komponen Daya Tarik Wisata dan Pengelolaan Pantai Labuan sait, Desa Pecatu,
Kabupaten Badung. Jurnal Ilmiah Pariwisata : unud.ac.id

Razak, Fitridamayanti, Benu Olfie L, Suzane Gene H.M. Kapantowo. 2017. Strategi Pengembangan Wisata Bahari Pantai Malayang, Kota Manado, Sulawesi Utara (Agri-SosioEkonomi Unsrat) Volume 13 1A

Rangkuti, Freedy. 2002. Analisis SWOT Teknik Membeda Kasus Bisnis. Gramedia Pustaka Utama. Jakarta

Sunarta, I Nyoman. 2011. Evaluasi Perkembangan Wisata Bahari di Pantai Sanur. Jurnal Ilmiah Pariwisata

Yoety, A. Oka. 2008 Perencanaan dan Pengembangan Pariwisata. Jakarta: Pradnya Paramita 